\title{
Pengaruh Ukuran Perusahaan Terhadap Return Yang Dimoderasi Oleh Profit Growth Pada Perusahaan Perbankan Di Bursa Efek Indonesia
}

\author{
MARLINDA SAPUTRI \\ Sekolah Tinggi Ilmu Ekonomi Persada Bunda \\ Jl. Diponegoro No. 43 Pekanbaru \\ E-mail : marlindasaputri@ymail.com
}

\begin{abstract}
This study aims to determine the effect of company size moderated by profit growth on rate return shares. The population in this study are banking company listed on Indonesia Stock Exchange (IDX). Purposive sampling method was used to determine the sample of banking companies whose published complete financial statements with positive equity shares on 2013-2017. Based on the criteria obtained a sample of 20 companies. Quantitative analysis method with multiple regression and t-test were used to test hypotheses. The result seen that there is no significant effect of company size on stock returns, and so does with the company size moderated by profit growth one.
\end{abstract}

Keywords: Company size, return, and profit growth

Berkembangnya pertumbuhan perekonomian di tanah air tidak terlepas dari peran vital yang diperlihatkan oleh sektor perbankan, sektor perbankan dipercaya telah memperkuat fundamental perekonomian nasional. Mengingat bank adalah tempat atau lembaga intermediasi sirkulasi dana investasi yang bersumber dari para pelaku dunia usaha dan investor menjadi bank pada saat ini memiliki peran yang sangat penting dalam menggerakkan perekonomian nasional. Dendawijaya (2005 : 7) mendefenisikan bank sebagai lembaga yang melakukan aktivitasnya pengumpulan dana dari deposan atau masyarakat dan kemudian disalurkan kembali kepada nasabah dalam bentuk kredit. Fenomena umum yang terjadi bahwa tantangan yang dihadapi dunia perbankan pada saat ini adalah terjadinya krisis ekonomi global yang melanda perekonomian negara kuat yang merambat hingga kawasan Asia Tenggara termasuk Indonesia. Untuk menghindari dampak krisis ekonomi global yang lebih serius bagi dunia perbankan. Maka bank yang eksis ditanah air terus berusaha berbenah untuk menjaga kestabilan kinerja keuangan yang mereka miliki. Untuk mengetahui kinerja keuangan sebuah perbankan dapat diketahui dengan melakukan analisis laporan keuangan. Secara umum didalam laporan keuangan terdapat poin-poin penting yang merupakan elemen pengukuran kinerja keuangan perbankan.

Adanya kelebihan dana yang dimiliki investor jika tidak dimanfaatkan secara optimal akan meninbulkan resiko bagi pemilik modal. Oleh sebab itu melakukan investasi pada salah satu jenis sekuritas adalah solusi terbaik yang dapat dilakukan investor. Jika hutang yang tinggi apabila dikelola secara optimal akan memberikan kontribusi profit yang tinggi sehingga nilai perusahaan dapat ditingkatkan. Dalam hal ini terjadi peningkatan profit yang optimum dan meningkatnya kesejahteraan investor yang berinvestasi didalam perusahaan.

Dalam perkembangan ekonomi global diseluruh dunia bahwa return dan resiko investasi sangat berkaitan satu sama lainnya. Dimana Tujuan investasi yaitu untuk mendapatkan keuntungan (return) yang diperoleh oleh investor dengan cara memaksimalkan keuntungan (return) dan akan memperkecil resiko kerugian. 
Dalam system perbankan untuik menjalankan suatu usaha tentu akan berharap untuk memperoleh keuntungan baik berupa expected return atau realized return. Expected return merupakan keuntungan yang sangat diharapkan oleh investor dimasa mendatang sedangakan realized return adalah tingkat return yang didapatkan investor pada masa yang lalu. Seorang pemberi modal yang memiliki jumlah saham yang besar biasanya akan semakin besar pula hak kepemilikan seoran pemilik modal ke perusahaan yang dimodalinya.

Besar kecilnya perusahaan bisa diukur dengan total active perusahaan yaitu menggunakan cara perhitungan logaritma nilai total aktiva. Informasi tentang ukuran perusahaan perlu bagi investor karena makin besar nilai ukuran perusahaan maka perusahaan akan lebih baik menghadapi resiko maupun peluang untuk mengembangkan apapun perluasan operasi. Ukuran perusahaan yang berbeda dapat mengakibatkan resiko yang berbeda Antara perusahaan yang besar dengan yang kecil. Resiko perusahaan yang besar akan mendapatkan resiko yang kecil karena perusahaan dianggap memiliki akses pasar modal sehingga akan lebih mudah dalam mendapatkan tambahn dana dan dapat menambah keuntungan.

Dalam pengambilan keputusan investasi pada surat berharga dan saham dapat dipengaruhi oleh berbagai fariabel salah satunya adalah ukuran perusahaan. Ukuran prusahaan yang lebih besar akan memudahkan perusahaan dalam berinvestasi karena perusahaan yang besar pada umumnya sudah dikenal masyarakat dan para investor lebih mudah mendapatkan informasi yang dibutuhkan untuk memprospek perusahaan tersebut, sehinggan tingkat resiko yang akan didapat investor akan lebih kecil.

$$
\text { Ukuran perusahaan }
$$
merupakan semua aktiva ( kekayaan ) yang ada di perusahaan yang dapat dilihat dari sebelah kiri neraca baik berupa aktiva tetap ataupun berupa aktiva lancar.
Ukuran perusahaan diukur dengan menggunakan total aktiva, modal atau penjualan dari perusahaan itu sendiri, dan yang menjadi tolak ukur yaitu besar kecilnya perusahaan berdasarkan ukran aktiva perusahaan tersebut. Perusahaan yang mempunyai total aktiva yang tinggi menunjukan perusahaan itu akan mencapai tingkat kedewasaan, dimana arus kas dalam tahap ini telah memiliki prosperk yang bagus dalam waktu jangka panjang.

Suharmadji ( 2007, 52) dalam penelitiannya dapat disimpulkan bahwa besarnya ukuran perusahaan dapat dilihat dalam total aktiva. Semakin besar penjualan semakin besar pula kapitalisasi pasar maka ukuran perusahaan akan semakin besar pula sehingga mengakibatkan semakin banyak modal yang ditanamkan maka semakin besar total aktiva yang didapatkan perusahaan.

Menurut Simamora (2000: 50) dapa disimpulkan bahwa besarnya laba suatu perusahaan dari tahun ke tahun akan berfluktuasi, kadang laba akan meningkat dan bisa juga menurun. Peningkatan laba yang terus menurus akan menunjukan pertumbuhan laba perusahaan yang bagus, demikian juga sebaliknya pertumbuhan laba yang menurun akan menunjukan pertumbuhan laba perusahaan yang tidak baik. Laba sangat berperan dalam menunjang kelangsungan hidup perusahaan.

Salah satu indicator penunjang kemajuan perusahaan adalah pertumbuhan laba. pertumbuhan laba yang baik akan menunjukan kinerja perusahaan yang baik, semakin tinggi pertumbuhan laba semakin bagus kinerja perusahaan demikian juga sebaliknya semakin menurun pertumbuhan laba perusahaan semakin menurun pula kinerja perusahaan tersebut. Jadi pertumbuhan laba bisa dilihat dari rasio keuangan perusahaan, semakin baik rasio keuangan semakin baik juga pertumbuhan laba perusahaan.

Menurut Arifin (2007 : 23) ukuran perusahaan akan mempengaruhi

p.ISSN: 2407-800X e.ISSN: 2541-4356 
peningkatan return yang diterima investor, karena besarnya cadangan ukuran perusahaan akan meningkatkan kemampuan perusahaan untuk membayarkan dan mengembalikan return kepada investor sehingga dapat disimpulkan bahwa semakin bagus ukuran perusahaan sebuah perusahaan akan semakin bagus pula return yang akan diterima oleh investor dan sebaliknya.

Menurut pendapat Raharjo (2007: 20) dapat disimpulkan bahwa ukuran perusahaan akan mempunyai pengaruh yang positif terhadap tingkat pengembalian (return), semakin meningkatnya ukuran perusahaan memperlihatkan semakin tingginya nilai assets atau kekayaan yang dimiliki perusahaan yang menjadi jaminan bagi investor untuk keamanan dalam berinvestasi, oleh sebab itu harga saham perusahaan cenderung mengalami peningkatan yang tentunya juga diikuti oleh peningkatan return. Hipotesis penelitian yang dapat dirumuskan yaitu: H1 : Ukuran perusahaan mempunyai pengaruh yang positif terhadap return.

Menurut Arifin (2007: 23) ukuran perusahaan akan mempengaruhi peningkatan return yang diterima investor, karena besarnya cadangan ukuran perusahaan untuk membayarkan return kepada investor. Dari pendapat diatas dapat disimpulkan bahwa semakin tinggi ukuran perusahaan akan mengakibatkan semakin tinggi pula nilai return yang akan diterima oleh investor.

Raharjo (2007: 18) mengungkapkan ukuran perusahaan berpengaruh akan memiliki pengaruh yang positif terhadap return, semakin meningkatnya ukuran perusahaan memperlihatkan semakin tingginya nilai assets atau kekayaan yang dimiliki perusahaan yang menjadi jaminan bagi investor untuk keamanan dalam berinvestasi.

Pertumbuhan laba pada perusahaan akan dapat meningkatkan ukura perusahaan sehingga nilai return akan berpengaruh menjadi tinggi ( adanya hubungan positif antara ukuran perusahaan dengan return). Ukuran perusahaan bisa dilihat dari active perusahaan itu sendiri, modal yang besar akan mengakibatkan total aktifa menjadi tinggi artinya semakin tinggi penjualan yang dilakukan perusahaan maka produk yang dihasilkan akan semakin terkenal dikalangan konsumen. Dari uraian tersebut bisa disimpulkan bahwa size memiliki pengaruh yang positif terhadap ukuran perusahaan dan return

Perusahaan yang mempunyai laba yang tidak berkembang akan berdampak pada ukuran perusahaan, akibatnya ukuran perusahaan berhubungan negative terhadap return yang didapatkan. Didalam penelitian Saputra ( 2004:23) menyatakan bahwa tingginya tingakat return yang diharapkan perusahaan akan mengakibatkan tinggi juga resiko yang akan dialami oleh perusahaan, demikian juga sebaliknya resiko semakin rendah jika perusahaan menginginkan return yang rendah. Return akan berpengaruh negative ketika laba perusahaan tidak berkembang dengan baik, sehingga didapat hipotesis ke 2 yaitu: $\mathrm{H} 2$ : Ukuran perusahaan akan berpengaruh positif terhadap return saham yang didukung dengan adanya profit growth.

\section{METODE}

Analisis Regresi Penelitian ini menggunakan analisis regresi linear berganda untuk menguji hipotesis. Adapun persamaan yang dipakai yaitu:

PL) $+\mathrm{e}$

$$
\mathrm{Y}=\alpha+\beta 1 \mathrm{UP}+\beta 2 \mathrm{PL}++\beta 3(\mathrm{UP}
$$

Keterangan :

$$
\begin{aligned}
\mathrm{Y}= & \text { variabel terikat Return } \\
\alpha= & \text { konstanta } \\
\mathrm{UP}= & \text { variabel bebas yaitu } \\
& \text { ukuran perusahaan } \\
\mathrm{PL}= & \text { variabel pemoderasi } \\
& \text { yaitu pertumbuhan laba } \\
\beta 1-\beta 3= & \text { koefisien regresi variabel } \\
& \text { bebas } \\
\text { ei }= & \text { error }
\end{aligned}
$$

\section{Uji Normalitas}

Menurut Nacrhrowi (2007 : 97) uji normalitas yaitu pengujian yang dipakai untuk melihat normal atau tidak normalnya 
pendistribusian data yang didapat dengan menggunakan uji jarque-bera. Variabel dikatakan normal jika nilai probability besar dari alpha 5\%. Jika semua variabel sudah berdistribusi normal atau nilai sudah diatas 5\% maka pengujian hipotesis sudah bisa dilakukan. Untuk menghitung nilai jarque bera statistik maka terlebih dahulu dilakukan nilai JB-hit yang dicari memakai rumus yaitu:

$$
I B=\frac{N-k}{6}\left(S^{2}+\frac{1}{4}(K-3)^{2}\right)
$$

\section{Uji Asumsi Klasik}

Sebelum melakukan pengujian secara statistik terlebih dahulu dilakukan uji asumsi klasik supaya hasil bias tidak didapat. Uji asumsi klasik yang dipakai yaitu:

a) Uji Multikolinearitas

Menurut Nachrowi (2007 : 178) uji multikolinearitas tujuannya untuk menguji apakah ada model regresi ditemukan pada suatu korelasi antar variabel independent, jika ada terjadi korelasi maka terdapat problem multikolinearitas. Pada model regresi yang baik ini tidak terjadi korelasi diantara suatu variabel independent, adanya beberapa cara yang dapat dilakukan untuk mendeteksi suatu gejala multikolinearitas yaitu dengan cara meregresi sesama variabel independent, apabila terdapat nilai koefisien korelasi (r) lebih besar dari 0,80 maka menandakan telah terjadi sebuah multikolinearitas, begitu juga dengan sebaliknya jika nilainya lebih kecil dari 0,80 maka dapat dikatakan tidak terjadi suat multikolinearitas, bila korelasi antara dua variabel bebas $>0,80$ maka terjadi masalah yang serius.

b) Uji Autokorelasi,

Untuk melacak adanya korelasi autokorelasi atau pengaruh data dari suatu pengamatan sebelumnya dalam model regresi yang diatas. Uji autokorelasi dapat dilakukan dengan cara bantuan program
Eviews.Durbin- Watson (D-W stat) dengan rumus (Gujarati, 2001) :

$$
\mathrm{d}=\frac{\sum_{t=2}^{n}\left(e_{1}-e_{t-1}\right)^{2}}{\sum_{t=1}^{n} e t^{2}}
$$

dimana:

$$
\begin{array}{ll}
\mathrm{d} & =\text { nilai } \mathrm{D}-\mathrm{W} \text { stat } \\
\text { et } & =\text { nilai residu pada periode } \mathrm{t} \\
\text { et-1 } & =\text { nilai residu pada periode } \mathrm{t}- \\
1 &
\end{array}
$$

c) Uji Heteroskedastisitas

Uji heteroskedasitas memiliki tujuan untuk melihat apakah ada ketidaksamaan dari varian satu observasi dengan residual suatu observasi yang lainnya. Jika varian satu dengan varian lainnya tetap maka dikatakan homoskedasitas tetapi jika berbeda maka disebut dengan heteroskedasitas. .

Ghozali (2001 : 81) mengatakan untuk melihat ada atau tidaknya heteroskedasitas maka dapat digunakan uji Glejser dengan syarat pengujian jika nilai heteroskedasitas memiliki tingkat kepercayaan diatas 0,05 maka tidak memiliki atau mengandung heteroskedasitas tetapi jika nilai dibawah 0,05 maka memiliki atau mengandung heteroskedasitas.

Berarti dapat disimpulkan bahwa syarat heteroskedasitas dengan memakai uji Glejser yaitu nilai probailitas $<0,05=$ adanya heteroskedasitas dan nilai probabilitas > 0,05 = tidak adanya heteroskedasitas.

\section{Uji Statistik}

Uji statistik dilakukan untuk melihat apakah ada pengaruh variabel independent terhadap dependent serta seberapa besar veriabel independent dan dependent memiliki pengaruh.

Rumus yang digunakan untuk menetukan $\mathrm{t}$ statistik yaitu: (Gujarati, 2001 : 74) 
$t=\frac{\beta n}{S \beta n}$

Dimana : $\beta \mathrm{n}=$ koefisien regresi variabel

$S \beta n=$ Standar error variabel

Kriteria penolakan dan penerimaan hipotasis

1. Jika nilai sig $<\alpha$ maka Ho ditolak dan Ha diterima artinya terdapat pengaruh variabel independent terhadap dependen.

2. Jika nilai sig $>\alpha$ maka Ho diterima dan $\mathrm{Ha}$ ditolak artinya tidak ada pengaruh signifikan antara variabel independent terhadap dependent.

\section{HASIL}

Berdasarkan hasil penelitian dengan cara menggunakan Eviews untuk membuktikan pengaruh suatu variabel independent terhadap variabel dependent ditemukan deskripsi data pada Tabel 1.1 sebagai berikut :

Tabel 1.1 Hasil Statistik Deskriptif

\begin{tabular}{|c|c|c|c|c|c|}
\hline $\begin{array}{c}\text { Variab } \\
\text { el }\end{array}$ & $\begin{array}{c}\text { Jumlah } \\
\text { data }\end{array}$ & $\begin{array}{c}\text { Maksi } \\
\text { mum }\end{array}$ & $\begin{array}{c}\text { Minim } \\
\text { um }\end{array}$ & Mean & $\begin{array}{c}\text { Standar } \\
\text { deviasi }\end{array}$ \\
\hline Return & 100 & 24,000 & - & 0,5809 & 2,740239 \\
Saham & & 00 & $\begin{array}{c}0,7872 \\
30\end{array}$ & 86 & \\
\hline $\begin{array}{c}\text { Ukuran } \\
\text { perusa } \\
\text { haan }\end{array}$ & 100 & 8,5544 & 5,9184 & 7,2686 & 0,760403 \\
\hline Profit & 100 & 10 & 20 & 62 & \\
Growth & & 80 & 6,4836 & 11 & \\
& & & 50 & & \\
\hline
\end{tabular}

Sumber: Hasil Pengolahan Data

Berdasarkan hasil deskriptif statistik dari tabel 1.1 dapat dijelaskan bahwa gambaran statistik dari variabel yang dipakai dalam penelitian ini. Untuk variabel yang diukur dengan variabel dependent return saham dan variabel independent ukuran perusahaan dan variabel pemoderasi pertumbuhan laba. Jumlah data yang dimiliki adalah sebanyak 100 yaitu dari 20 perusahaan yang tergolong pada saham perusahaan perbankan yang telah terdaftar di Bursa Efek Indonesia (BEI) dalam jangka waktu 5 tahun sejak 2013 sampai dengan tahun 2017.
Untuk variabel dependen adalah return saham dengan nilai Maksimum dan Minimum harga saham yang dimiliki perusahaan yang tergolong dalam saham perusahaan perbankan adalah 24,00000 dan $-0,787230$, didapat nilai rata-rat peningkatan return sebesar 0,580986, dengan standar deviasi peningkatan return yaitu 2,740239.

Untuk variabel independen pertama adalah Ukuran perusahaan dengan nilai Maksimum dan Minimum dengan peningkatan harga saham yang bergerak di bidang perbankan adalah 8,554410 dan 5,918420, dengan nilai rata-rata peningkatan ukuran perusahaan sebanyak 7,268662 dengan nilai standar deviasi peningkatan ukuran perusahaan sebesar 0,760403 .

Untuk variabel terakhir adalah pertumbuhan laba dengan nilai Maksimum dan Minimum dengan peningkatan harga saham yang bergerak di bidang perbankan adalah 6,927580 dan $-6,483650$, didapat nilai rata-rata peningkatan pertumbuhan laba sebanyak 0,127511 nilai standar deviasi peningkatan pertumbuhan laba sebanyak 1,337232 .

Uji normalitas diuji ketika kita belum melakukan uji hipotesis yang digunakan untuk melihat distribusi data yang mendukung variabel yang akan diteliti. Jika variance yang mengukur variabel penelitian dinyatakan telah berdistribusi mengikuti pola garis lurus maka variabel penelitian dinyatakan telah berdistribusi normal.

Uji normalitas digunakan dengan menggunakan uji Probabilitas Jarque Bera. Adapun pengambilan keputusan adalah apabila nilai Probabilitas Jarque Bera < $0,05=$ tidak berdistribusi normal, dan apabila nilai Probabilitas Jarque Bera > $0,05=$ berdistribusi normal. Dari hasil pengujian normalitas data yang telah dilakukan pada perusahaan perbankan yang telah memenuhi kriteria ditemukan tidak normal. Dimana hasil penelitian awal uji normalitas dapat dilihat pada penyajian Tabel 2.2 berikut:

Tabel 2.2: Hasil Uji Awal Normalitas Data 


\begin{tabular}{|c|c|c|c|}
\hline Variabel & Probabilitas & Alpha & Kesimpulan \\
\hline Return & 0,000000 & 0,05 & $\begin{array}{c}\text { Tidak } \\
\text { berdistribusi } \\
\text { Normal }\end{array}$ \\
\hline $\begin{array}{c}\text { Ukuran } \\
\text { Perusah } \\
\text { aan }\end{array}$ & 0,036592 & 0,05 & $\begin{array}{c}\text { Tidak } \\
\text { berdistribusi } \\
\text { Normal }\end{array}$ \\
\hline $\begin{array}{c}\text { Profit } \\
\text { grwoth }\end{array}$ & 0,000000 & 0,05 & $\begin{array}{c}\text { Tidak } \\
\text { berdistribusi } \\
\end{array}$ \\
& & & Normal \\
\hline
\end{tabular}

Sumber: Hasil Pengolahan Data

Untuk menormalkan data tersebut maka seluruh nilai data yang ekstrim atau outlier dari perusahaan tersebut dihapus atau diganti dengan nilai rata-rata dari deskriptif statistik yang kemudian uji normalitas dilakukan kembali. Setelah dilakukan uji normalitas kembali, barulah penilitian tersebut berdistribusi normal. Berdasarkan hasil uji normalitas tersebut ditemukan seluruh variabel penelitian telah berdistribusi secara normal karena dalam pengujian ditemukan nilai Probabilitas Jarque Bera > 0.05 bisa dilihat dalam penyajian Tabel 2.3 berikut:

Tabel 2.3 Hasil Pengujian Normalitas Jarque Bera

\begin{tabular}{|c|c|c|c|c|}
\hline Variabel & $\begin{array}{c}\text { Jarque } \\
\text { Bera }\end{array}$ & $\begin{array}{c}\text { Profita } \\
\text { bility }\end{array}$ & Alpha & Kesimpulan \\
\hline $\begin{array}{c}\text { Return } \\
\text { Saham }\end{array}$ & $\begin{array}{c}3,35992 \\
5\end{array}$ & $\begin{array}{c}0,186 \\
381\end{array}$ & 0,05 & Normal \\
\hline $\begin{array}{c}\text { Ukuran } \\
\text { Perusahaa } \\
\mathrm{n}\end{array}$ & $\begin{array}{c}1,09406 \\
9\end{array}$ & $\begin{array}{c}0,578 \\
663\end{array}$ & 0,05 & Normal \\
\hline $\begin{array}{c}\text { Pertumbu } \\
\text { han Laba }\end{array}$ & $\begin{array}{c}1,96389 \\
2\end{array}$ & $\begin{array}{c}0,374 \\
581\end{array}$ & 0,05 & Normal \\
\hline
\end{tabular}

Sumber: Hasil Pengolahan Data

Berdasarkan tabel 2.3 dapat dilihat dalam pengujian hipotesis didapat nilai Probabilitas Jarque Bera > alpha 0.05. Penulis menyimpulkan bahwa data yang telah disajikan yang dipakai dalam penelitian adalah berdistribusi normal, jadi penelitian ini bisa dilanjutkan ke tahap berikutnya.

Uji hipotesis digunakan untuk mengetahui apakah hipotesis akan diterima atau tidak. Yang mana dapat dilihat melalui tahapan pengujian hipotesis sebagai berikut

\section{Persamaan Regresi}

Analisa regresi linear berganda dimaksudkan untuk melihat pengaruh Profit growth dijadikan sebagai variabel pemoderasi terhadap ukuran perusahaan, return dan membuktikan secara nyata apakah hipotesis diterima atau ditolak. Setelah olah data yang dilakukan maka didapat persamaan regresi Linear Berganda yaitu:

Tabel 2.4: Hasil Persamaan Regresi Linear Berganda

\begin{tabular}{|c|c|c|c|}
\hline Variabel & $\begin{array}{c}\text { Koefisien } \\
\text { Korelasi }\end{array}$ & Std. Error & t-hit \\
\hline C & $-0,419116$ & 1,470013 & 0,285111 \\
\hline UP & 0,068554 & 0,157084 & 0,436415 \\
\hline PL & 1,364311 & 2,815550 & 0,484563 \\
\hline UPPL & $-0,088035$ & 0,279463 & $-0,315014$ \\
\hline
\end{tabular}

Sumber: Hasil pengolahan data

Dari nilai koefisien regresi yang tersaji diatas, dapat dibuat sebuah persamaan regresi linear berganda yaitu: $\mathrm{Y}=-0,419116+0,068554 \mathrm{UP}+$ 1,364311PL - 0,088035UPPL + e

Nilai konstanta dari persamaan diatas sebesar $-0,419116$ hal ini memperlihatkan jika ukuran perusahaan, Pertumbuhan Laba, ukuran perusahaan yang dimoderasi oleh pertumbuhan laba diasumsikan konstan maka return saham akan menurun sebanyak -0,419116.

Variabel (UP) yaitu ukuran perusahaan, yang memiliki nilai koefisien regresi dengan nilai 0,068554 jadi ukuran perusahaan memiliki pengaruh positif terhadap return saham maksudnya bila ukuran perusahaan naik ( meningkat) maka return saham juga akan eningkat sebesar 0,068554 yang diasumsikan faktor lain selain ukuran perusahaan dianggap konstan.

Variabel (PL) yaitu Pertumbuhan laba, yang memiliki nilai koefisien regresi 
sebesar 1,364311 hal ini menandakan bahwa profith growth memiliki pengaruh positif terhadap return saham, artinya ketika profit growth naik maka return saham juga akan meningkat sebanyak 1,364311 dengan asumsi faktor lain selain profit growth dianggap konstan.

Variabel (UPPL) yaitu Nilai koofisien regresi sebanyak $-0,088035$ merupakan ukuran perusahaan yang dimoderasi dengan profit growth menandakan ukuran perusahaan yang dimoderasi oleh profit growth memiliki pengaruh yang negatif terhadap return saham, artinya bila ukuran perusahaan dimoderasi oleh profit growth meningkat maka return akan menurun sebesar $-0,088035$ yang diasumsikan faktor lain yang dimoderasi oleh profit growth dianggap konstan.

Untuk membuktikan pengaruh pemoderasi pertumbuhan laba terhadap ukuran perusahaan dengan return, bagi para investor yang berinvestasi di perbankan yang listing di BEI, maka dilakukan uji hipotesis menggunakan uji t-statistik. Berdasarkan hasil pengolahan data dengan menggunakan koefisien regresi maka didapat hasil uji hipotesis yang dapat disajikan Tabel 1.5:

Tabel 1.5: Hasil Pengujian Hipotesis

\begin{tabular}{|c|c|c|c|}
\hline Variabel & $\begin{array}{c}\text { Probabil } \\
\text { ity }\end{array}$ & $\begin{array}{c}\text { Alp } \\
\text { ha }\end{array}$ & Kesimpulan \\
\hline Ukuran Perusahaan & 0,6636 & 0,05 & $\begin{array}{c}\text { Tidak } \\
\text { Signifikan }\end{array}$ \\
\hline $\begin{array}{c}\text { Ukuran Perusahaan } \\
\text { dimoderasi oleh } \\
\text { pertumbuhan laba }\end{array}$ & 0,7535 & 0,05 & $\begin{array}{c}\text { Tidak } \\
\text { Signifikan }\end{array}$ \\
\hline
\end{tabular}

Sumber: Hasil olahan Data

Dilihat dari Tabel 1.5 hasil pengujian hipotesis pertama dengan variabel ukuran perusahaan diperoleh nilai probability sebanyak 0,6636 dengan alpha 0,05 sehingga nilai $0,6636>0,05$ artinya ukuran perusahaan tidak mempunyai pengaruh yang signifikan terhadap return saham.

Berdasarkan hasil pengujian hipotesis kedua dengan variabel ukuran perusahaan Jurnal Daya Saing (Vol. 4, No. 3 Oktober 2018) dimoderasi oleh pertumbuhan laba diperoleh nilai probability sebanyak 0,7573 dengan alpha 0,05 sehingga nilai $0,7573>$ 0,05 , artinya ukuran perusahaan dimoderasi oleh profit growth tidak mempunyai pengaruh yang signifikan terhadap return.

\section{PEMBAHASAN}

Setelah dilakukan uji hipotesis didapat ukuran perusahaan tidak mempunyai pengaruh yang signifikan terhadap return saham. Penyebabnya adalah assets yang tersimpan didalam perusahaan digunakan untuk membiayai aktifitas diluar operasional seperti untuk pengembangan usaha, sehingga assets atau ukuran perusahaan tidak mempunyai pengaruh yang signifikan terhadap hasil yang didapatkan oleh investor ketika berinvestasi.

Hasil yang diperoleh di dalam penelitian ini didukung oleh penelitian Nova (2003 : 45) dalam penelitiannya size perusahaan juga tidak mempunyai pengaruh terhadap return saham penyebabnya adalah ukuran perusahaan menggambarkan kekayaan yang tersimpan didalam perusahaan. Adanya asset yang menganggur akan mempengaruhi penjualan yang dihasilkan perusahaan sehingga image dan pendangan investor terhadap perusahaan menjadi negatif yang akan mempengaruhi penurunan return yang dihasilkan perusahaan.

Berdasarkan hasil pengujian hipotesis kedua ditemukan ukuran perusahaan terhadap return yang dimoderasi oleh profit growth tidak mempunyai pengaruh signifikan, penyebabnya adalah assets yang tersimpan di dalam perusahaan digunakan untuk membiayai aktifitas luar operasional seperti untuk pengembangan usaha, sehingga ukuran perusahaan tidak mempunyai pengaruh terhadap return yang diterima investor dalam berinvestasi.

Hasil yang diperoleh di dalam penelitian ini didukung oleh penelitian Hamid (2001 : 50) dalam penelitiannya ukuran perusahaan tidak mempunyai

p.ISSN: $2407-800 X \quad$ e.ISSN: 2541-4356 
pengaruh yang signifikan terhadap return yang dimoderasi oleh profit growth, penyebabnya adalah pertumbuhan laba yang meningkat akan membuat tingkat return yang didapatkan oleh investor tinggi jadi investor cendrung akan mempertahankan saham, sehingga investor tidak akan menjualnya sehingga tidak mempengaruhi return yang akan diterima investor.

\section{SIMPULAN}

Dari hasil penelitian diatas dapat diberikan kesimpulan yaitu: Dalam hipotesis pertama didapat bahwa ukuran perusahaan tidak mempunyai pengaruh yang signifikan terhadap return dan Sedangkan hipotesis kedua didapatkan hasil ukuran perusahaan tidak mempunyai pengaruh yang signifikan terhadap retun yang dimoderasi oleh profit growth.

\section{DAFTAR RUJUKAN}

Arifin, M, Sajakin. 2001. Analisis Laporan Keuangan Lanjutan. Yogyakarta

Brigham, Euene F dan Joel F. Houstan. 2001. Manajemen Keuangan. Jilid 2, alih bahasa Didit Suharto dan Hera wibowo, edisi ke 8, Erlangga. Jakarta.

Foster, Bandstadler. 2007. Financial Management and Statedment. Diterjemahkan oleh Ayu Novalinda. Pustaka Gramedia. Jakarta

Ghozali., Imam., 2001. Dasar-Dasar SPSS dan Aplikasi. BPFE. Yogyakarta

Hasan, Marzuki.2003. Pengaruh Kinerja Keuangan Terhadap Perubahan Harga Saham Pada Perusahaan Perbankan di Bursa Efek Indonesia. Jurnal Manajemen Universitas Ghunadarma. Jakarta

Hermansyah. 2007. Bank dan Lembaga Keuangan New Edition. Erlangga. Jakarta
Irmayanti. 2005. Uji Normalitas One Sample Kolmogorov Smitnov Test. www.Google.com/uji normalitas

Kasmir. 2006. Manajemen Perbankan. Jakarta : Rajagrafindo Persada.

Lupiu. 2007. Pengaruh Size, Leverange, Inventory Turnover dan Profitabilitas Terhadap Return Saham Perusahaan Manufaktur di BEI. Jurnal Manajemen Keuangan Universitas Kristen Petra. Surabaya

Nachrowi, De Nochrowi. 2007. DasarDasar Aplikasi Statistik melalui SPSS dan Penerapan Eviews. BPFE. Yogyakarta

Novirman, Wisnu. 2006. Pengaruh Kinerja Perusahaan Terhadap Return SahamPada Perusahaan Perbankan yang go Public di BEI. Skripsi Mahasiswa Jurusan Manajemen Universitas Andalas. Padang

Riyanto., Bambang.. 2001. Dasar-Dasar Pembelajaran Perusahaan. Edisi tiga.Yayasan Badan Penerbit Gadjah Mada. Yogyakarta.

Santi. 2007. Pengaruh Faktor Fundamental Terhadap Tingkat Pengembalian Investasi. Jurnal Universitas Islam Indonesia. Yogyakarta

Santoso, Singgih. 2001. Dasar-Dasar SPSS dan Aplikasi. Gramedia Pustaka. Jakarta

Sudjoko. 2007. Pengeruh Ukuran Perusahaan Kepemilikan Manajerial,

KepemilikanInstitusional dan Leverange Terhadap Tingkat Pengembalian Investasi Pada Perusahaan Manufaktur di BEJ. Jurnal Manajemen Keuangan Universitas Ghunadharma. Jakarta 
Tandelilin, Eduardus. 2001. Dasar-Dasar Manajemen Keputusan Investasi dan Manajemen Portofolio. BPFE. Yogyakarta 